\title{
GROWTH PERFORMANCE OF JUTE (Corchorus capsularies L.) AS INFLUENCED BY DIFFERENT ORGANIC MANURES
}

\author{
Qulsum, U., F. F. Meem, R. S. Promi, J. R. Zaman, M. F. Ara and M. K. Rahman \\ Department of Soil, Water and Environment, University of Dhaka, Dhaka-1000, Bangladesh
}

\begin{abstract}
A pot experiment was carried out in 2019 in the net house of the Department of Soil, Water and Environment, University of Dhaka, to evaluate the growth and yield of Jute plants (Corchorus capsularies $\mathbf{L}$.) by applying different types of organic manures. Eight different types of organic manures viz. ACI, BGF-1, Mazim, Vermicompost, Shufola, GTS, Green and Poultry manures were collected from the local market. The experiment was set up following a completely randomized design (CRD) with nine treatments and three replications consisting of twenty-seven pots. Significant variation was observed in different growth and yield contributing characters. The highest plant height $(19.83 \mathrm{~cm})$ in poultry manure, leaf number $(8.33 /$ plant $)$ was observed in Green manure, leaf area $\left(21.93 \mathrm{~cm}^{2} /\right.$ plant $)$ in Poultry manure, fresh weight $(3.18 \mathrm{~g})$ and dry weight $(2.25 \mathrm{~g})$ were found in Poultry manure, stem girth $(1.67 \mathrm{~cm} / \mathrm{plant})$ in Vermicompost, branch number (8.6/plant) in Green manure. The highest nutrient uptake by plants $(\mathrm{kg} / \mathrm{ha})$ occurred in Poultry manure. The overall best growth was observed in Poultry manure.
\end{abstract}

Key words: Soil organic carbon; Organic manure; Jute.

\section{INTRODUCTION}

Organic matter is the storehouse of all the plant nutrients in the soil. It is the major source of two important mineral elements of $\mathrm{P}$ and $\mathrm{S}$, and essentially the sole source of $\mathrm{N}$. It is equally important in improving soil structural conditions, water and nutrient holding capacity, and microbial activities for successful cultivation. Soil organic matter (SOM) is an important soil component that affects soil biological and soil physicochemical properties (Bhardwaj et al. 2011). SOM influences soil quality and nutrient processes, such as soil fertility, physical structure, and soil nutrient availability. Manure is an organic matter used as sources of plant nutrients (organic fertilizer in agriculture). They contain plant nutrients in complex organic forms. Poor soil fertility resulting from low organic matter content is a major production constraint in Bangladesh. Better soil fertility with higher organic matter content is a prerequisite for sustainable crop production, and organic manure can play a role in increasing soil fertility and crop production. The application of organic manure has been reported to increase crop yield and improve soil quality, especially soil organic matter content (Garg et al. 2005, Islam et al. 2010). By using organic manure, we can create an integrated, sustainable agricultural system, relying first and foremost on ecological interactions and biological processes for the crop, livestock and human nutrition and can get protection from pests and diseases. Organic farming is a matter of giving back to nature what we take from it. It is safe, inexpensive, profitable and sensible. Organic manures produce optimal conditions in the soil for high yields and good quality crops. They reduce the need for purchased inputs as most of the organic manures are wastes or by-products, which on accumulation may lead to pollution. By way of utilizing them for organic farming, pollution is minimized. Organic matter restores the $\mathrm{pH}$ of the soil, which may become acidic due to the continuous application of chemical manures. Organically grown crops are believed to provide healthier and nutritionally superior food for men and animals than those grown with commercial manures. Organic farming helps to prevent environmental degradation and can be used to regenerate degraded areas.

India, China, and Bangladesh are the three major producers in the cultivation or production of jute fiber in the world. In Bangladesh, the jute fiber grown in this region is further divided into two major varieties-hard district jute and soft district jute. The fibers are used alone or blended with other types of 
fibers to make twine and rope. Jute butts, the coarse ends of the plants, are used to make inexpensive cloth. Conversely, very fine threads of jute can be separated and made into imitation silk. Jute fibers are also used for making pulp of paper. Jute requires a warm and humid climate with a temperature between $24^{\circ}-37^{\circ} \mathrm{C}$ but the optimum range of temperature required is $18^{\circ}-33^{\circ} \mathrm{C}$. Jute is cultivated in the rainy season, constant rain or water-logging is harmful. In Bangladesh sowing usually starts at the end of February and continues up to the end of May, depending on the species. Cultivation largely depends upon pre-monsoon showers and moisture conditions. The new gray alluvial soil of good depth is the best for jute. Jute is grown widely in sandy loams and clay loams. The objective of the experiment was to determine the change of physico-chemical properties of soil due to the application of different organic manure and growth performance of jute (Corchorus capsularies L.) as influenced by different organic manures.

\section{Soil sample collection and analysis}

\section{METERIAL AND METHODS}

The soil sample was collected from the village-Ati, upazilla-Keraniganj, district-Dhaka, Bangladesh. The samples were ground, sieved and passed through a $2 \mathrm{~mm}$ sieve. Then the soil was preserved in plastic bottles and labeled properly. These were used for physico-chemical analysis by the following method.

Soil moisture content was $12.32 \%$ (Miller and Donahue 1965), sand $15.05 \%$, silt $70.58 \%$,clay $14.37 \%$, soil textural class - Silty loam (Bouyoucos 1962) The matrix color of soil was evaluated by visual examination in outdoor sunlight with Munsell color plates which was 2.5 YR 7/1 (Light reddish gray). The $\mathrm{pH}$ of the soil samples was 7.5 (1:2.5 w/v H2O, Jackson 1965). The EC of the soil samples was $162.8 \mu \mathrm{S}(1: 5 \mathrm{w} / \mathrm{v} \mathrm{H} 2 \mathrm{O}$, Jackson 1965). The organic carbon content of soils was $0.41 \%$ (Walkley and Black 1934). The organic matter (O.M.) was calculated by multiplying carbon by the factor of 1.72 . Available nitrogen in the samples was $24 \mathrm{mg} / \mathrm{kg}$ (Kjeldahl extraction, Jackson 1965), available P was 6 $\mathrm{mg} / \mathrm{kg}$ (Blue color method using ascorbic acid, Olsen et al. 1954), exchangeable K was $3 \mathrm{cmol} / \mathrm{kg}$ (Pratt, 1965), available Sulphur was $4.8 \mathrm{mg} / \mathrm{kg}$ (Turbidimetric method: Bardsley and Lancaster 1965).

\section{Collection of organic manures}

Eight different types of organic manures were collected from the local market manufactured by different companies. The name of the manures were Poultry, ACI, Vermicompost, BGF, GTS, Shufola, Mazim and Green and the N, P, K content (\%) were 0.9-1.5, 0.5, 0.8; 0.5-4.0, 0.5-3.0, 0.5-3.0; 3.0-5.0, 3.0-5.0, 3.0-5.0; 0.04-0.06, 0.071-0.085, 0.42-0.54; biogas slurry; 15.0, 15.0, 15.0; 0.5-4.0, 0.5-3.0, 0.5$3.0 ; 1.1,0.67,1.15$ respectively.

\section{Pot Experiment}

Six kilogram of soil was used per earthen pot (height $22 \mathrm{~cm}$ and diameter $26 \mathrm{~cm}$ ). Fertilizers from different companies like Poultry, ACI, Vermicompost, BGF, GTS, Shufola, Mazim, and Green were applied. Six ton /ha organic manures with three replications were applied. Manures were properly mixed separately with soil. Pots were arranged in a complete randomized design (CRD) in the net house of the Department of Soil, Water and Environment, University of Dhaka. 6kg/ha N, $12 \mathrm{~kg} / \mathrm{ha} \mathrm{P}$ and $12 \mathrm{~kg} / \mathrm{ha} \mathrm{K}$ as urea, TSP and Murate of potash was given as a basal dose of nitrogen, phosphorus and potassium respectively (BARC 2018). A control experiment without any manure was also set up and replicated 3 times.

Seeds were collected from Siddik Bazar, Dhaka, Bangladesh. Five to six seeds of jute were sown per pot. After germination three healthy seedlings were allowed to grow. Seedlings were watered daily in the morning. The height, number of leaves and leaf area of the plants were measured at 15 days interval. 
Height was measured from the surface of the soil to the tip of the leaf of the seedlings. Intercultural operations were done when needed. Leaf area was determined according to Kayode and Tedela (2005) as: $\mathrm{A}=\mathrm{L} \times \mathrm{B} \times 0.75$ where $\mathrm{A}=$ length of the leaf, $\mathrm{B}=$ breadth the leaf and $0.75=$ constant.

\section{Harvesting}

Three months old jute plants were harvested as leaf, stem, root, washed with tap water and finally with distilled water and wrapped with soft tissue paper. Immediately after harvest, fresh weight of leaf, stem and root were taken and then air-dried in the room temperature and finally oven-dried at $65^{\circ}{ }_{\mathrm{C}}$ in the laboratory for 24 hours. The dry weight of the samples was recorded and ground with a mechanical grinder and stored in the polythene bags for further chemical analysis.

Statistical analysis: Statistical analysis was done using Minitab 17.

\section{Plant growth assessment}

\section{RESULTS AND DISCUSSION}

Plant growth was assessed in terms of height (Table 1), leaf number (Table 2), leaf area (Table 3), branch number (Table 3), stem girth (Table 4), plants fresh and dry weights (Table 5), length of roots (Table 5). The result of experiments indicated that all the treatments increased the plant growth parameter as compared to control.

\section{Plant height}

Seedlings were allowed to grow 90 days and harvested as root, stem and leaf. The longest height recorded was $19 \mathrm{~cm}$ in Green manure on 90DAS and the least height was recorded in 1.54 at control on 15 DAS (Table 3). There is no significant difference in height among the treatments and control pot after 15 and 30 days of sowing. The significant difference among control and treatments were started after 45 DAS and it continued up to 90 DAS.

Table 1. Effects of different manures on the height $(\mathrm{cm})$ of Jute plants at fifteen days interval.

\begin{tabular}{lcccccc}
\hline Treatments & \multicolumn{6}{c}{ Days after sowing } \\
\cline { 2 - 6 } (6 ton/ha) & $\mathbf{1 5 d}$ & $\mathbf{3 0 d}$ & $\mathbf{4 5 d}$ & $\mathbf{6 0 d}$ & $\mathbf{7 5 d}$ & $\mathbf{9 0 d}$ \\
\hline Control(-OM) & $1.54^{\mathrm{a}}$ & $1.62^{\mathrm{a}}$ & $1.81^{\mathrm{b}}$ & $5.21^{\mathrm{b}}$ & $8.69^{\mathrm{b}}$ & $9.96^{\mathrm{b}}$ \\
Poultry & $2.83^{\mathrm{a}}$ & $3.75^{\mathrm{a}}$ & $6.17^{\mathrm{a}}$ & $11.33^{\mathrm{a}}$ & $14.67^{\mathrm{a}}$ & $19.83^{\mathrm{a}}$ \\
ACI & $3.17^{\mathrm{a}}$ & $4.08^{\mathrm{a}}$ & $5.42^{\mathrm{a}}$ & $9.67^{\mathrm{a}}$ & $11.67^{\mathrm{a}}$ & $12.17^{\mathrm{a}}$ \\
Vermicompost & $2.83^{\mathrm{a}}$ & $4.00^{\mathrm{a}}$ & $5.33^{\mathrm{a}}$ & $8.33^{\mathrm{a}}$ & $11.33^{\mathrm{a}}$ & $13.33^{\mathrm{a}}$ \\
BGF & $3.33^{\mathrm{a}}$ & $4.33^{\mathrm{a}}$ & $5.17^{\mathrm{a}}$ & $8.33^{\mathrm{a}}$ & $10.00^{\mathrm{a}}$ & $12.33^{\mathrm{a}}$ \\
GTS & $3.50^{\mathrm{a}}$ & $4.25^{\mathrm{a}}$ & $5.17^{\mathrm{a}}$ & $9.67^{\mathrm{a}}$ & $8.33^{\mathrm{a}}$ & $12.00^{\mathrm{a}}$ \\
Shufola & $3.83^{\mathrm{a}}$ & $4.50^{\mathrm{a}}$ & $4.33^{\mathrm{a}}$ & $10.83^{\mathrm{a}}$ & $16.00^{\mathrm{a}}$ & $17.50^{\mathrm{a}}$ \\
Mazim & $3.50^{\mathrm{a}}$ & $4.82^{\mathrm{a}}$ & $6.15^{\mathrm{a}}$ & $9.17^{\mathrm{a}}$ & $13.67^{\mathrm{a}}$ & $15.00^{\mathrm{a}}$ \\
Green & $3.17^{\mathrm{a}}$ & $4.33^{\mathrm{a}}$ & $5.67^{\mathrm{a}}$ & $10.83^{\mathrm{a}}$ & $16.83^{\mathrm{a}}$ & $16.69^{\mathrm{a}}$ \\
\hline LSD at 5\% & $\mathbf{1 . 6 3}^{\mathrm{a}}$ & $\mathbf{1 . 6 2}$ & $\mathbf{1 . 8 1}$ & $\mathbf{5 . 2 1}$ & $\mathbf{8 . 6 9}^{\mathrm{9.96}}$ \\
\hline
\end{tabular}

Means bearing the same letters along the column are no significantly different $(\mathrm{P}<0.05)$ according to Duncan's New Multiple Range Test.

Chindo and Khan (1986) reported that the addition of organic manure in the soil improves soil health and hence encourage the plant good root and lead to higher plants. This might be due to the nitrogen concentration provided by manure that resulted in the increase of the vegetative growth of $C$. olitorius. Senjobi et al. (2013) noted that poultry manure produced the highest value in plant height and stem girth of $C$. olitorius. 


\section{Leaf number}

Leaf number/plant differed with time, although after 90 days, Green treated plant showed the highest number of leaves, 8.33 leaves/plant (Table 2). It was observed that control had the lowest production of leaves (3 leaves/ plant). Leaf number/plant increased gradually through 15, 30, 45, 60, 75 and 90 DAS. After 45 days of sowing there is no significant difference among the treatments and the control. After 60 days of sowing there is no significant difference among Poultry, ACI, Vermicompost, GTS, Mazim and Green but there is significant difference among control, Green, Mazim, Shufola, BGF, ACI and Poultry. There is significant difference between control and Shufola after 75 days of sowing. After 90 days of sowing there is no significant difference among control and Poultry, ACI, Vermicompost, BGF, GTS and Shufola.

Table 2. Effects of different organic manures on the leaf number/plant of Jute plants at fifteen days interval.

\begin{tabular}{|c|c|c|c|c|c|c|}
\hline \multirow{2}{*}{$\begin{array}{l}\text { Treatments } \\
6 \text { ton/ha }\end{array}$} & \multicolumn{6}{|c|}{ Days after sowing } \\
\hline & $15 d$ & 30d & $45 d$ & 60d & $75 d$ & 90d \\
\hline Control(-OM) & $4.00^{\mathrm{a}}$ & $5.00^{b}$ & $4.50^{\mathrm{a}}$ & $3.00^{\mathrm{d}}$ & $4.00^{\mathrm{bcd}}$ & $4.00^{\mathrm{c}}$ \\
\hline Poultry & $3.67^{\mathrm{ab}}$ & $4.33^{\mathrm{a}}$ & $5.00^{\mathrm{a}}$ & $6.67^{\mathrm{ab}}$ & $5.30^{\mathrm{abc}}$ & $7.00^{\mathrm{abc}}$ \\
\hline ACI & $3.33^{\mathrm{ab}}$ & $4.00^{\mathrm{a}}$ & $4.33^{\mathrm{a}}$ & $5.00^{b}$ & $4.33^{\mathrm{cd}}$ & $4.67^{\mathrm{c}}$ \\
\hline Vermicompost & $3.00^{\mathrm{b}}$ & $4.00^{\mathrm{a}}$ & $5.33^{\mathrm{a}}$ & $5.67^{\mathrm{bd}}$ & $5.33^{\mathrm{abcd}}$ & $6.33^{\mathrm{abc}}$ \\
\hline BGF & $3.00^{\mathrm{a}}$ & $3.67^{\mathrm{a}}$ & $4.67^{\mathrm{a}}$ & $6.33^{\mathrm{a}}$ & $5.67^{\mathrm{abcd}}$ & $6.67^{\mathrm{abc}}$ \\
\hline GTS & $3.67^{\mathrm{ab}}$ & $4.00^{\mathrm{a}}$ & $4.67^{\mathrm{a}}$ & $5.67^{\mathrm{bd}}$ & $5.33^{\text {abcd }}$ & $6.30^{\mathrm{abc}}$ \\
\hline Shufola & $3.33^{\mathrm{ab}}$ & $4.00^{\mathrm{a}}$ & $4.67^{\mathrm{a}}$ & $7.33^{\mathrm{ac}}$ & $4.67^{\mathrm{a}}$ & $8.31^{\mathrm{bc}}$ \\
\hline Mazim & $3.00^{b}$ & $4.00^{\mathrm{a}}$ & $4.33^{\mathrm{a}}$ & $6.33^{\mathrm{ab}}$ & $7.33^{\mathrm{ab}}$ & $8.00^{\mathrm{ab}}$ \\
\hline Green & $3.33^{\mathrm{ab}}$ & $4.00^{\mathrm{a}}$ & $4.67^{\mathrm{a}}$ & $6.33^{\mathrm{ab}}$ & $7.67^{\mathrm{ab}}$ & $8.33^{\mathrm{a}}$ \\
\hline LSD at $5 \%$ & 0.77 & 0.86 & 2.163 & 1.29 & 2.71 & 3.62 \\
\hline
\end{tabular}

This result is in line with the work of Madisa et al. (2013) that the good performance of $C$. olitorius was shown by treatment with chicken manure. Masarirambi et al. (2010) reported that organic manure has been found to enhance the number of leaves in lettuce by providing a sufficient amount of nutrients that accelerate the growth of leaves. The increase in the number of leaves and yield was due to increased solubilization effect and availability of nutrients by the addition of organic manures relatively results in better development of more leaves (Tovihoudji et al. 2015).

\section{Branch number}

There is a significant difference among control and all other treatments after 60,75 and 90 days of sowing in respect of branch number. Marti and Millis (1991) noted that an adequate supply of nitrogen is associated with vigorous vegetative growth resulting from high photosynthetic activities. Nitrogen is very important for photosynthetic activity and vegetative growth. The study by Kavanova et al. (2008) asserted that nitrogen deficiency severely reduced leaf blade growth by increasing cell cycle duration and decreasing mitotic and post - mitotic rates.

\section{Leaf area}

Leaf areas $\left(\mathrm{cm}^{2} /\right.$ plant) of jute plants were highest in Poultry which was 21.93 at 90 DAS (Table 3). After 30 days of sowing, there is a significant difference in leaf area among control and Poultry, ACI, Vermicompost, BGF, GTS. There is no significant difference among Shufola, Mazim, Green and control after 60 days of sowing. After 60 days of sowing there is no significant difference among Vermicompost, BGF, GTS, Shufola, Mazim, Green and control. After 90 days of sowing there is a significant difference between Poultry and control in respect of leaf area. Poultry manure treatment showed the highest leaf area after 90 days. This result is according to Balyeri et al. (2016) who found that the Poultry manure increased the leaf area due to sufficient nitrogen availability which in turn 
improves the vegetative growth of the crop. By applying organic manure nitrogen is increased and as a result branch number per plant increased over control.

Table 3. Effects of different organic manures on branch number and leaf area of Jute plants.

\begin{tabular}{l|ccc|ccc}
\hline \multirow{2}{*}{$\begin{array}{l}\text { Treatments } \\
\text { 6 ton/ha }\end{array}$} & \multicolumn{3}{|c|}{$\begin{array}{c}\text { Branch (no./plant) } \\
\text { Days after sowing }\end{array}$} & \multicolumn{3}{c}{$\begin{array}{c}\text { Leaf area }\left(\mathbf{c m}^{2} / \mathbf{p l a n t}\right) \\
\text { Days after sowing }\end{array}$} \\
\cline { 2 - 7 } & $\mathbf{6 0 d}$ & $\mathbf{7 5 d}$ & $\mathbf{9 0 d}$ & $\mathbf{6 0 d}$ & $\mathbf{7 5 d}$ & $\mathbf{9 0 d}$ \\
\hline Control (-OM) & $4.15^{\mathrm{g}}$ & $4.18^{\mathrm{g}}$ & $4.21^{\mathrm{f}}$ & $1.95^{\mathrm{b}}$ & $4.15^{\mathrm{bc}}$ & $5.27^{\mathrm{b}}$ \\
Poultry & $5.34^{\mathrm{f}}$ & $5.5^{\mathrm{f}}$ & $5.7^{\mathrm{e}}$ & $11.17^{\mathrm{a}}$ & $20.10^{\mathrm{a}}$ & $21.93^{\mathrm{a}}$ \\
ACI & $6.5^{\mathrm{d}}$ & $7.4^{\mathrm{e}}$ & $7.6^{\mathrm{d}}$ & $12.80^{\mathrm{ac}}$ & $8.06^{\mathrm{c}}$ & $10.66^{\mathrm{b}}$ \\
Vermicompost & $8.3^{\mathrm{a}}$ & $8.5^{\mathrm{c}}$ & $9.0^{\mathrm{a}}$ & $3.23^{\mathrm{d}}$ & $4.50^{\mathrm{b}}$ & $8.37^{\mathrm{b}}$ \\
BGF & $7.2^{\mathrm{c}}$ & $7.5^{\mathrm{cd}}$ & $8.1^{\mathrm{c}}$ & $2.00^{\mathrm{d}}$ & $4.60^{\mathrm{b}}$ & $6.57^{\mathrm{b}}$ \\
GTS & $6.4^{\mathrm{e}}$ & $7.3^{\mathrm{de}}$ & $7.5^{\mathrm{d}}$ & $2.88^{\mathrm{d}}$ & $5.80^{\mathrm{b}}$ & $10.37^{\mathrm{b}}$ \\
Shufola & $7.1^{\mathrm{c}}$ & $7.8^{\mathrm{b}}$ & $8.4^{\mathrm{b}}$ & $4.33^{\mathrm{bd}}$ & $14.87^{\mathrm{b}}$ & $17.33^{\mathrm{a}}$ \\
Mazim & $6.8^{\mathrm{d}}$ & $7.8^{\mathrm{bc}}$ & $8.5^{\mathrm{b}}$ & $4.13^{\mathrm{bd}}$ & $5.73^{\mathrm{b}}$ & $7.33^{\mathrm{b}}$ \\
Green & $7.5^{\mathrm{b}}$ & $8.1^{\mathrm{a}}$ & $8.6^{\mathrm{b}}$ & $4.83^{\mathrm{bd}}$ & $9.33^{\mathrm{b}}$ & $12.45^{\mathrm{b}}$ \\
\hline LSD at 5\% & $\mathbf{0 . 1 3}$ & $\mathbf{0 . 1 4}$ & $\mathbf{0 . 1 3}$ & $\mathbf{5 . 3 2}$ & $\mathbf{1 3 . 7 3}$ & $\mathbf{6 . 9 4}$ \\
\hline
\end{tabular}

Stem girth

A calibrated Vernier caliper was used to measure the stem girth. There is no significant difference among Poultry, BGF and control after 45 days of showing. There is a significant difference with control and GTS, Mazim, Shufola after 45 days of showing. There is a significant difference among control and Shufola, Vermicompost, Green, Mazim, ACI and Poultry manure. There is a significant difference among control and GTS, Mazim, Green, Shufola and Vermicompost after 60 days of showing. There is a significant difference among BGF, Mazim, ACI, Green, Shufola, Vermicompost after 90 days of showing. Opeyemi and Adegboyega (2003) noted that animal manure increased the number of leaves, stem girth and leaf length.

Table 4. Effects of different organic manures on stem girth $(\mathrm{cm})$ of Jute plants.

\begin{tabular}{lcccccc}
\hline Treatments & \multicolumn{6}{c}{ Days after sowing } \\
\cline { 2 - 7 } 6 ton/ha & $\mathbf{1 5 d}$ & $\mathbf{3 0 d}$ & $\mathbf{4 5 d}$ & $\mathbf{6 0 d}$ & $\mathbf{7 5 d}$ & $\mathbf{9 0 d}$ \\
\hline Control (-OM) & $0.2^{\mathrm{d}}$ & $0.4^{\mathrm{b}}$ & $0.7^{\mathrm{cd}}$ & $0.9^{\mathrm{d}}$ & $1.2^{\mathrm{ef}}$ & $1.4^{\mathrm{c}}$ \\
Poultry & $0.4^{\mathrm{a}}$ & $0.7^{\mathrm{a}}$ & $0.9^{\mathrm{cd}}$ & $1.1^{\mathrm{bc}}$ & $1.3^{\mathrm{de}}$ & $1.5^{\mathrm{bc}}$ \\
ACI & $0.2^{\mathrm{d}}$ & $0.6^{\mathrm{b}}$ & $0.9^{\mathrm{bcd}}$ & $1.2^{\mathrm{abc}}$ & $1.3^{\mathrm{cde}}$ & $1.5^{\mathrm{ab}}$ \\
Vermicompost & $0.4^{\mathrm{ab}}$ & $0.7^{\mathrm{a}}$ & $1.2^{\mathrm{a}}$ & $1.1^{\mathrm{b}}$ & $1.4^{\mathrm{a}}$ & $1.67^{\mathrm{a}}$ \\
BGF & $0.3^{\mathrm{d}}$ & $0.5^{\mathrm{b}}$ & $0.8^{\mathrm{cd}}$ & $1.0^{\mathrm{cd}}$ & $1.1^{\mathrm{f}}$ & $1.6^{\mathrm{ab}}$ \\
GTS & $0.4^{\mathrm{ab}}$ & $0.6^{\mathrm{b}}$ & $1.0^{\mathrm{ab}}$ & $1.1^{\mathrm{cd}}$ & $1.3^{\mathrm{bcd}}$ & $1.5^{\mathrm{bc}}$ \\
Shufola & $0.3^{\mathrm{bcd}}$ & $0.7^{\mathrm{a}}$ & $1.2^{\mathrm{a}}$ & $1.3^{\mathrm{a}}$ & $1.4^{\mathrm{ab}}$ & $1.5^{\mathrm{ab}}$ \\
Mazim & $0.3^{\mathrm{cd}}$ & $0.5^{\mathrm{b}}$ & $0.9^{\mathrm{bc}}$ & $1.0^{\mathrm{abc}}$ & $1.4^{\mathrm{abc}}$ & $1.6^{\mathrm{ab}}$ \\
Green & $0.4^{\mathrm{abc}}$ & $0.6^{\mathrm{b}}$ & $0.8^{\mathrm{d}}$ & $1.2^{\mathrm{abc}}$ & $1.3^{\mathrm{ab}}$ & $1.6^{\mathrm{ab}}$ \\
\hline LSD at 5\% & $\mathbf{0 . 0 8}$ & $\mathbf{0 . 0 9}$ & $\mathbf{0 . 1 1}$ & $\mathbf{0 . 1 1}$ & $\mathbf{0 . 0 9}$ & $\mathbf{0 . 0 9}$ \\
\hline
\end{tabular}

Fresh weight, dry weight and root length

The yields of fresh and dry weights of root and shoot are presented individually in Table 5. Control pots had the least dry matter content. Poultry manure showed the highest total fresh weight and dry weight that are $3.18 \mathrm{~g} /$ plant and $2.25 \mathrm{~g} /$ plant respectively. The lowest total fresh weight and lowest total dry weight were shown by BGF which are $0.42 \mathrm{~g} /$ plant and $0.25 \mathrm{~g} / \mathrm{plant}$ respectively. The highest value of the fresh weight of root was $0.71 \mathrm{~g} /$ plant for fresh weight and $0.45 \mathrm{~g} / \mathrm{plant}$ for dry weight. The highest length of the root is $7.5 \mathrm{~cm}$ showed by the Shufola and the lowest length is $3.8 \mathrm{~cm}$ showed by ACI. In the case of the root-shoot ratio, the highest value is 1.74 of Vermicompost and the lowest value is 0.06 of Green. Shufola and Mazim showed the same root-shoot ratio i.e. 0.12 (Table 5). 
Table 5: Effects of different organic manure on biomass production of Jute plants.

\begin{tabular}{l|ccc|ccc|c|c}
\hline \multirow{2}{*}{$\begin{array}{l}\text { Treatments } \\
\text { 6 ton/ha }\end{array}$} & \multicolumn{3}{|c|}{ Fresh weight (g/plant) } & \multicolumn{3}{|c|}{ Dry weight (g/plant) } & Root Length & Root/shoot \\
\cline { 2 - 6 } & Root & Shoot & Total & Root & Shoot & Total & (cm) & ratio \\
\hline Control(-OM) & 0.16 & 0.26 & $0.42^{\mathrm{a}}$ & 0.04 & 0.37 & $0.41^{\mathrm{a}}$ & $5.25^{\mathrm{a}}$ & $0.11^{\mathrm{c}}$ \\
Poultry & 0.71 & 2.47 & $3.18^{\mathrm{b}}$ & 0.45 & 1.80 & $2.25^{\mathrm{a}}$ & $5.57^{\mathrm{a}}$ & $0.25^{\mathrm{f}}$ \\
ACI & 0.23 & 1.27 & $1.50^{\mathrm{ab}}$ & 0.11 & 0.62 & $0.73^{\mathrm{a}}$ & $3.80^{\mathrm{a}}$ & $0.18^{\mathrm{e}}$ \\
Vermi compost & 0.12 & 0.94 & $1.06^{\mathrm{ab}}$ & 0.40 & 0.23 & $0.63^{\mathrm{a}}$ & $6.10^{\mathrm{a}}$ & $1.74^{\mathrm{d}}$ \\
BGF & 0.07 & 0.77 & $0.84^{\mathrm{a}}$ & 0.03 & 0.22 & $0.25^{\mathrm{a}}$ & $5.33^{\mathrm{a}}$ & $0.14^{\mathrm{b}}$ \\
GTS & 0.31 & 0.84 & $1.15^{\mathrm{ab}}$ & 0.15 & 0.66 & $0.81^{\mathrm{a}}$ & $5.00^{\mathrm{a}}$ & $0.23^{\mathrm{f}}$ \\
Shufola & 0.35 & 1.94 & $2.29^{\mathrm{ab}}$ & 0.16 & 1.31 & $1.47^{\mathrm{a}}$ & $7.5^{\mathrm{a}}$ & $0.12^{\mathrm{c}}$ \\
Mazim & 0.14 & 0.61 & $0.75^{\mathrm{a}}$ & 0.06 & 0.50 & $0.56^{\mathrm{a}}$ & $4.43^{\mathrm{a}}$ & $0.12^{\mathrm{c}}$ \\
Green & 0.31 & 2.01 & $2.32^{\mathrm{ab}}$ & 0.07 & 1.10 & $1.17^{\mathrm{a}}$ & $5.07^{\mathrm{a}}$ & $0.06^{\mathrm{a}}$ \\
\hline LSD at 5\% & - & - & $\mathbf{2 . 2 1}$ & - & - & $\mathbf{1 . 6 6}$ & $\mathbf{3 . 2 0}$ & $\mathbf{0 . 0 2}$ \\
\hline
\end{tabular}

This was in accordance with the work of Adenawoola and Adejoro (2005) who found that poultry manure increased the growth and yield of $C$. olitorius. Said (1997) reported that the addition of organic manures increase the plant growth characteristics such as plant height, number of leaves and shoot per plant including fresh root and shoot weights.

\section{Chemical properties}

Organic manure increases the organic matter status of the soil and enhances crop production.

\section{Plant nutrients uptake}

There is a significant difference among the control experiment and other treatments in respect of nutrient uptake by plants (Table 6). The average $\mathrm{N}$ uptake in the plants ranged from 34.20 to 109.95 $\mathrm{kg} / \mathrm{ha}$. The average $\mathrm{P}$ uptake in the plants ranged from 15.50 to $30.30 \mathrm{~kg} / \mathrm{ha}$. The average $\mathrm{K}$ uptake in the plants ranged from 72.8 to $166 \mathrm{~kg} / \mathrm{ha}$.

Table 6. Effects of different organic manures on nutrients uptake of Jute plants (kg/ha).

\begin{tabular}{lccc}
\hline Treatments & \multicolumn{3}{c}{ Nutrients uptake by plants (kg/ha) } \\
\cline { 2 - 4 } & Nitrogen & Phosphorus & Potassium \\
\hline Control (-OM) & $34.20^{\mathrm{i}}$ & $15.50^{\mathrm{i}}$ & $72.8^{\mathrm{i}}$ \\
Poultry & $106.50^{\mathrm{a}}$ & $30.30^{\mathrm{a}}$ & $166^{\mathrm{a}}$ \\
ACI & $89.63^{\mathrm{d}}$ & $25.60^{\mathrm{e}}$ & $140.67^{\mathrm{c}}$ \\
Vermicompost & $109.95^{\mathrm{b}}$ & $29.2^{\mathrm{b}}$ & $162^{\mathrm{b}}$ \\
BGF & $104.40^{\mathrm{c}}$ & $26.10^{\mathrm{d}}$ & $138.70^{\mathrm{d}}$ \\
GTS & $81.6^{\mathrm{e}}$ & $28.7^{\mathrm{c}}$ & $135.7^{\mathrm{e}}$ \\
Shufola & $75.90^{\mathrm{f}}$ & $22.10^{\mathrm{h}}$ & $120^{\mathrm{f}}$ \\
Mazim & $70.90^{\mathrm{h}}$ & $23.15^{\mathrm{g}}$ & $117^{\mathrm{h}}$ \\
Green & $72.8^{\mathrm{g}}$ & $24.68^{\mathrm{f}}$ & $118.42^{\mathrm{g}}$ \\
\hline LSD at 5\% & $\mathbf{0 . 2 4}$ & $\mathbf{0 . 1 4}$ & $\mathbf{0 . 1 4}$ \\
\hline
\end{tabular}

Poultry is a good soil amendment that increases the water holding capacity and beneficial biota in soil. Poultry manure can be one of the greatest assets for farmers. It is the vast resource of nitrogen, phosphorus and potassium. These findings are at par with those reported by Munir et al. (2007) who also suggested that there is a positive effect of organic fertilization resulted from the increased water holding capacity and granulated soil structure which increases the efficiency of plant nutrients uptake.

\section{Residual values of the soils}

All these manures effect to change the soil $\mathrm{pH}$ with the organic way due to its major manure nutrients. The $\mathrm{pH}$ of post-harvest soil (after 90 days of planting) of control, Poultry, ACI, 
Vermicompost, BGF, GTS, Shufola, Mazim and Green treatments are 7.5, 7.4, 7.6, 7.4, 7.4, 7.4, 7.2, 7.4, 7.3, respectively (Table 7). The lowest $\mathrm{pH}$ value of post-harvest soil is 7.2 in Shufola treated soil sample and the highest $\mathrm{pH}$ value 7.6 is for ACI. This could be due to the fact that the organic manure had a relatively high buffering capacity based on its high organic matter content.

Table 7. pH, EC, Organic Carbon and Organic matter of post-harvest.

\begin{tabular}{lcccc}
\hline Treatment & $\mathbf{p H}$ & $\mathbf{E C}(\boldsymbol{\mu S})$ & Organic Carbon $(\%)$ & Organic matter $(\%)$ \\
\hline Control $(-\mathrm{OM})$ & 7.5 & 162.8 & 0.40 & 0.688 \\
Poultry & 7.4 & 112.3 & 1.05 & 1.806 \\
ACI & 7.6 & 103.8 & 1.44 & 2.4768 \\
Vermicompost & 7.4 & 456.0 & 2.03 & 3.4916 \\
BGF & 7.4 & 123.4 & 1.74 & 2.9928 \\
GTS & 7.4 & 156.7 & 2.88 & 4.9536 \\
Shufola & 7.2 & 263.0 & 1.21 & 2.0812 \\
Mazim & 7.4 & 168.9 & 1.05 & 1.806 \\
Green & 7.3 & 300.0 & 0.88 & 1.5136 \\
\hline
\end{tabular}

Electrical conductivity of Control, Poultry, ACI, Vermicompost, BGF, GTS, Shufola, Mazim and Green treatments are $162.8 \mu \mathrm{S}, 112.3 \mu \mathrm{S}, 103.8 \mu \mathrm{S}, 456.0 \mu \mathrm{S}, 123.4 \mu \mathrm{S}, 156.7 \mu \mathrm{S}, 263.0 \mu \mathrm{S}, 168.9 \mu \mathrm{S}$ and $300.0 \mu \mathrm{S}$, respectively.

Post-harvest soil analysis showed that the soil organic matter values were higher than initial sample. In control, the organic carbon was $0.40 \%$. Due to applying organic manure, the amount of organic carbon increased i.e. Poultry, ACI, Vermicompost, BGF, GTS, Shufola, Mazim and Green treatments contains $1.05,1.44,2.03,1.74,2.88,1.21,1.05$ and $0.88 \%$ organic carbon, respectively. GTS treated soil contain the higher amount of organic carbon $2.88 \%$ and Green manure treated soil contain the lowest amount of organic carbon $0.88 \%$ but not less than control $(0.40 \%)$. So, organic manure improves the organic carbon content of the soil. Though GTS produces highest amount of organic carbon, the results revealed that the most effective manure was Poultry compost so far growth performance. Olanikan (2006) noted that Application of organic manure has significant effects on plants height, leaves number, leaf area, fresh and dry weight of jute and the length of root, branch number, stem girth and uptake of nutrients by plants. Presence of organic carbon in the post-harvest soil increases due to the application of organic manure. Thus, a proper soil nutrient through applying organic manure is beneficial for improving soil health and jute production. This study is expected to provide valuable clues to enhance productivity through a balance use of organic manure. The findings and information of the study will be helpful for researchers and ultimately for the jute growers.

\section{REFERENCES}

Adenawoola, A. R. and S. A. Adejoro. 2005. Residual effects of poultry manure and NPK Fertilizer residues on soil nutrient and performance of Jute (Corchorus olitorius L.). Nigerian J. Soil Sci. 15: 133-135.

Balyeri, P. K., G. T. Otitoju, N. E. Abu and S. Umeh. 2016. Poultry manure influenced growth, yield and nutritional quality of containerized aromatic pepper. Afr. J. Agric. Res.11: 2013-2023.

BARC (Bangladesh Agricultural Research Council). 2018. Fertilizer Recommendation Guide. Soil publication no. 45. Bangladesh Agricultural Research Council, Dhaka, Bangladesh. 53 pp.

Bardsley, C. E. and J. D. Lancaster. 1965. Sulfur. In: C. A. Black (ed.). Methods of Soil Analysis. Part 2. American Society of Agronomy, Inc., Madison, Wisconsin, USA., pp. 1102-1114.

Bhardwaj, A. K., P. Jasrotia, S. K. Hamilton and G. P. Robertson. 2011. Ecological management of intensively cropped agro-ecosystems improves soil quality with sustained productivity. Agr. Ecosyst. Environ. 40: 419-29.

Bouyoucos G. J. 1962. Hydrometer method improved for making particle size analysis of soils. Agron. J. 54:461-465. 
Chindo, D. S and F. A. Khan. 1986. Effect of soil organic amendments with poultry manures on damage caused by the root-knot nematode, Meloidogyne incognita on tomato. Int. Nematol. Network Newsl. 3: 30-33.

Garg, R. N., H. Pathak, D. K. Das and R. K. Tomar. 2005. Use of fly ash and bio slurry for improving wheat yields and physical properties of soil. Environ. Monitoring Assess. 107: 1-9.

Islam, M. R., S. M. E. Rahman, M. M. Rahman, D. Hwan and R. C. Six. 2010. The effects of biogas slurry on the production and quality of maize fodder. Turk. J. Agric. For. 34: 91-99.

Jackson, M. L. 1965. Soil chemical analysis. Prentice-Hall Inc., New York, USA. 498 pp.

Kavanova, M., F. A. Lattanzi and H. Schnyder. 2008. Nitrogen deficiency inhibits leaf blade growth in Lolium perenne by increasing cell cycle duration and decreasing mitotic and post-mitotic growth rates. Plant Cell Environ. 31: 727-737.

Kayode, J. and P. O. Tedela. 2005. Effects of irrigation frequency on growth and nodulation of Leucaena leucocephala. Pak. J. For. 554(1): 33-40.

Madisa, M. E., T. Mathowa, C. Mfofu, N. A. Stephen and S. Machacha. 2013. Effect of chicken manure and commercial fertilizer on performance of jute mallow (Corchorus olitorus). Agri. Biol. J. North Am. 4(6): 617-622.

Marti, A. R. and H. A. Millis. 1991. Nutrient Uptake and yield of Sweet pepper as affected by stage of development and N. form. J. Plant Nutri. 14(11): 165-175.

Masarirambi, M. T., M. M. Hlawe, O. T. Oseni and T. E. Sibiya. 2010. Effects of organic fertilizers on growth, yield, quality and sensory evaluation of red lettuce (Lactuca sativa L.) 'Veneza Roxa'. Agric. Biol. J. N. Am. 1(6): 1319-1324.

Miller, W. R. and L. R. Donahue. 1965. An Introduction to Soils and Plant Growth. 6th ed. Pretence Hall Ltd., London, UK. 632 pp.

Munir, M. A., M. A. Malik and F. M. Saleem. 2007. Impact of integration of crop manuring and nitrogen application on growth yield and quality of spring planted sunflower (Helianthus annuus L.). Pak. J. Bot. 39(2): 441-449.

Olanikan, P. C. 2006. Organic manure as soil amendments in eroded tropical soil of south western Nigeria. $J$. Trop. Soil. 5(3): 11-18.

Olsen, S. R., C. V. Cole, F. S. Watanabe and L. A. Dean. 1954. Estimation of available phosphorus in soils by extraction with sodium bicarbonate. U.S. Dept. Agr. Circ. 939 pp.

Opeyemi, S. O. and A. A. Adegboyega. 2003. To investigate the separate and combined effect of urea and goat dung on leaf nutrient contents, growth and yield of Celosia argentea in south western Nigeria. Niger. Agric. J. 34: 87-90.

Pratt, P. F. 1965. Potassium. In: C. A. Black (ed). Methods of Soil Analysis. Part 2. American Society of Agronomy, Inc., Madison, Wisconsin, USA., pp. 1022-1030.

Said, A. H. 1997. Influence of some organic fertilizers on the growth and yield of pepper plants (Capsicum annum L.) cultivated under plastic houses. MSc Thesis. Fac. Agric., Ainshams Univ. Egypt. 164 pp.

Senjobi, B. A. 2013. Sandy soil improvement using organic materials and mineral fertilizers on the yield and quality of jute plant (Corchorus olitorius). J. Biol. Life Sci. 4(1): 219-233.

Tovihoudji, G. P., C. P. Djogbenou, P. B. I. Akponikpe, E. Kpadonou, C. E. Agbanga and D. G. Dagbenonbakin. 2015. Response of Jute Mallow (Corchorus olitorius L.) to organic manure and inorganic fertilizer on a ferruginous soil in North Eastern Benin. J. Applied Bio Sci. 92: 8610-8619.

Walkley, A. and I. A. Black. 1934. An examination of the Degtjareff method for determining soil organic matter and a proposed modification of the chromic acid titration method. Soil Sci. 37: 29-38. 